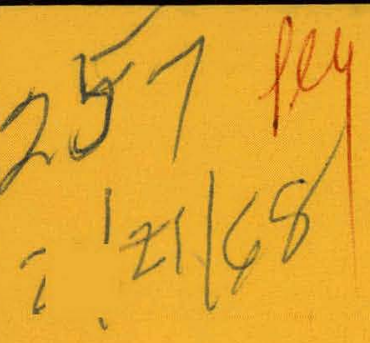

IN-1159

January 1968

\title{
VERSATILE SPECTROPHOTOMETRIC METHOD FOR THE DETERMINATION OF MICROGRAM AMOUNTS OF MERCURY
}

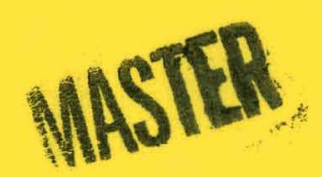

F. Fullerton and S. S. Yamamura

\section{IDAHO NUCLEAR CORPORATION NATIONAL REACTOR TESTING STATION IDAHO FALLS, IDAHO}




\section{DISCLAIMER}

This report was prepared as an account of work sponsored by an agency of the United States Government. Neither the United States Government nor any agency Thereof, nor any of their employees, makes any warranty, express or implied, or assumes any legal liability or responsibility for the accuracy, completeness, or usefulness of any information, apparatus, product, or process disclosed, or represents that its use would not infringe privately owned rights. Reference herein to any specific commercial product, process, or service by trade name, trademark, manufacturer, or otherwise does not necessarily constitute or imply its endorsement, recommendation, or favoring by the United States Government or any agency thereof. The views and opinions of authors expressed herein do not necessarily state or reflect those of the United States Government or any agency thereof. 


\section{DISCLAIMER}

Portions of this document may be illegible in electronic image products. Images are produced from the best available original document. 
Printed in the United States of America Available from

Clearinghouse for Federal Scientific and Technical Information National Bureau of Standards, U. S. Department of Commerce Springfield, Virginia 22151

Price: Printed Copy \$3.00; Microfiche $\$ 0.65$

\section{LEGAL NOTICE}

This report was prepared as an account of Government sponsored work. Neither the United States, nor the Commission, nor any person acting on behalf of the Commission:

A. Makes any warranty or representation, express or implied, with respect to the accuracy, completeness, or usefulness of the information centained in this report, or that the use of any information, apparatus, method, or process disclosed in this report may not infringe privately owned rights; or

B. Assumes any liabilities with respect to the use of, or for damages resulting from the use of any information, apparatus, method, or process disclosed in this report.

As used in the above, "person acting on behalf of the Commission" includes any employee or contractor of the Commission, or employee of such contractor, to the extent that such employee or contractor of the Commission, or employee of such contractor prepares, disseminates, or provides access to, any information pursuant to his employment or contract with the Commission, or his employment with such contractor. 
IN-1159

Issued: January 1968

Chemistry

TID-4500

VERSATILE SPECTROPHOTOMETRIC METHOD FOR THE DETERMINATION

OF MICROGRAM AMOUNTS OF MERCURY

F. Fullerton, S. S. Yamamura

\begin{abstract}
LEGAL NOTICE
This report was propared as an account of Government sponsored work. Nelther the United This report was prepared as an account of Government sponsored work. Nelthe
States, nor the Commisglon, nor any person acting on behalf of the Commission:

A. Makes any warranty or representation, expressed or implied, with respect to the accuracy, completeness, or usefulness of the informetion contained in this report, or that the ure of any information, apparatus, method, or process disclosed in this report may not infringe privately ounod righto; or

B. Assumes any liabilities with respect to the use of, or for damages resulting from the use of any information, apparatus, method, or process disclosed in this report.

As used in the above, "person acting on behalf of the Commisalon" includes any employee or contractor of the Commission, or employee nf sirnh contractor, to the oxtent ulat such employee or contractor of the Commisaion, or employee of euch contractor prepares, disseminates, or provides access to, any fnformation pursuant to his employment prepares, with the 'Ditiundsolun, ur lily tinploymebt with such contractor.

- $-\ldots, \ldots$
\end{abstract}

\title{
IDAHO NUCLEAR CORPORATION
}

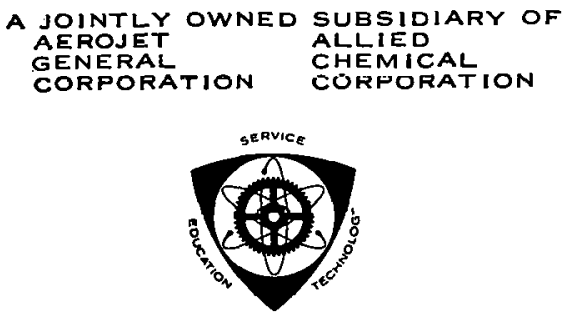

U. S. Atomic Energy Commission Research and Development Report

Issued Under Contract AT(10-1)-1230

Idaho Operations Office 


\begin{abstract}
A method is presented for the determination of mercury in a variety of inorganic and organic samples. After selected pretreatments, the mercury dithizonate complex is extracted from an EDTA-citrate medium into chloroform, the absorbance of which is measured at $495 \mathrm{m \mu}$.

The effects of 35 metal ions and 8 nonmetal anions have been studied. Only silver(I) interferes at less than a 50 to 1 molar ratio.
\end{abstract}


Three different pretreatments followed by a spectrophotometric method have been developed to determine mercury at microgram levels in a variety of inorganic and organic solutions and solids. Inorganic solutions are reacted with hot nitric acid to oxidize mercury to the (II) oxidation state. Inorganic solids are dissolved in acids or fused with potassium pyrosulfate. Organic materials or inorganic materials that contain organic matter are digested with a nitric-sulfuric acid mixture.

In the spectrophotometric method, the mercury(II) dithizone complex is extracted into chloroform and measured at $495 \mathrm{m \mu}$. A single extraction of the complex from an EDTA-citrate masking medium is sufficient when the concentrations of copper and silver are below established limits. A double extraction increases the tolerance for copper. In this double extraction procedure, the complex is extracted into chloroform from either an acidic $(\leq 0.75 \mathrm{~N})$ medium or the EDTA-citrate masking. medium at $\mathrm{pH} 2.85 \pm 0.35$. Mercury is stripped from the chloroform phase with an acidic nitrite solution, the nitrite is destroyed with hydroxylamine and aniline, and mercury(II) dithizonate is extracted a second time into chloroform.

The method is highly selective. Of 35 metal ions and 8 nonmetal anions studied in the double extraction procedure, only silver(I) interferes at a molar ratio to mercury below 50 to 1 . 
CONTENTS

$\underline{\text { Page }}$

ABSTRACT . . . . . . . . . . . . . . . . . . . . $i i$

SUMMARY. . . . . . . . . . . . . . . . . . . . . . . iii

INTRODUCTION . . . . . . . . . . . . ......... I

EXPERIMENTAL AND DISCUSSION. . . . . . . . . . . . . . . I

Variables in the Spectrophotometric Method. . . . . . . . 3

Extraction Acidity̆. . . . . . . . . . . . . . . 3

EDTA-Citrate Level. . . . . . . . . . . . . . 3

Stripping Conditions. . . . . . . . . . . . . . 3

Destruction of Nitrite and Nitrogen Oxides. . . . . . . . 3

Diverse Ion Effects. . . . . . . . . . . . . . . . 4

Sensitivity. . . .................. . 4

Precioion. . . . . . . . . . . . . . . . . . 4

REFERENCES ........................... . . . 7

APPENDIX . . . . . . . . . . . . . . . . . . . . 9

\section{TABLES}

I. DIVERSE ION EFFECTS ON THE SINGLT EXTRACTION PROCEDURE $\cdot \cdots \cdot \quad 5$

FIGURES

1. ANALYSIS SCHEME. . . . . . . . . . . . . . 2

A-1. DIGESTION APPARATUS FOR ORGANIC SAMPLES. . . . . . . . . 12 


\section{INTRODUCTION}

In a processing plant for the recovery of uranium from irradiated nuclear fuels, a variety of samples which contain mercury is analyzed. The mercury usually is introduced as mercury(II) nitrate to catalyze the nitric acid dissolution of aluminum clad fuels. Samples include the dissolution reagent, the dissolved fuel at various stages in the plant process, waste streams, and streams from the calcination process. (1) In the calcination process, the liquid waste is converted to micron-size solid particles by fluidized bed evaporation. During this process, mercury tends to volatilize to the environs. Vegetation samples often are analyzed for mercury to monitor for the release of mercury. In addition, miscellaneous samples of paints, inks, cardboards, and plastics are analyzed.

\section{EXPERTMENTAL AND DISCUSSION}

In general, the extraction-spectrophotometric method is patterned after a British method. (2) Some of the apparatus and several details of the method have been changed. The major effort was the development of pretreatment procedures for various inorganic and organic samples to increase versatility. The pretreatments and the extraction-spectrophotometric method are schematically diagrammed in Figure I and the detailed procedure is given in the Appendix.

Inorganic solutions are heated with nitric acid to make certain all the mercury is in the (II) oxidation state. The oxidation step is done in a test tube heated in a hot water bath.

Inorganic solids are fused with potassium pyrosulfate in a quartz tube with a water-condenser reflux seclion. During the fusion, much of the mercury volatilizes as free mercury or as mercury compounds into the condenser and must be returned to the tube. To accomplish this, the condenser water is turned off until the level of refluxing nitric acid nearly reaches the top of the condenser at which time it is turned on and the heating is continued until the melt dissolves.

Organic materials and aqueous solutions which contain organic materials are digested with a mixture of nitric acid and sulfuric acid in the apparatus pictured in Figure A-l in the Appendix. With this apparatus, the nitric acid. which distills from the digestion flask may be returned to the flask as required.

In all three pretreatment procedures, precautions must be taken to prevent the loss of mercury compounds, many of which volatilize from heated solutions. Using a Hg-203 tracer, losses of about $8 \%$ were obtained when organic materials were digested in the apparatus described by the British workers. (2) The addition of a vapor trap, shown in Figure A-1 of the Appendix, gives quantitative recovery of mercury. 
Solid Inorganic Samples

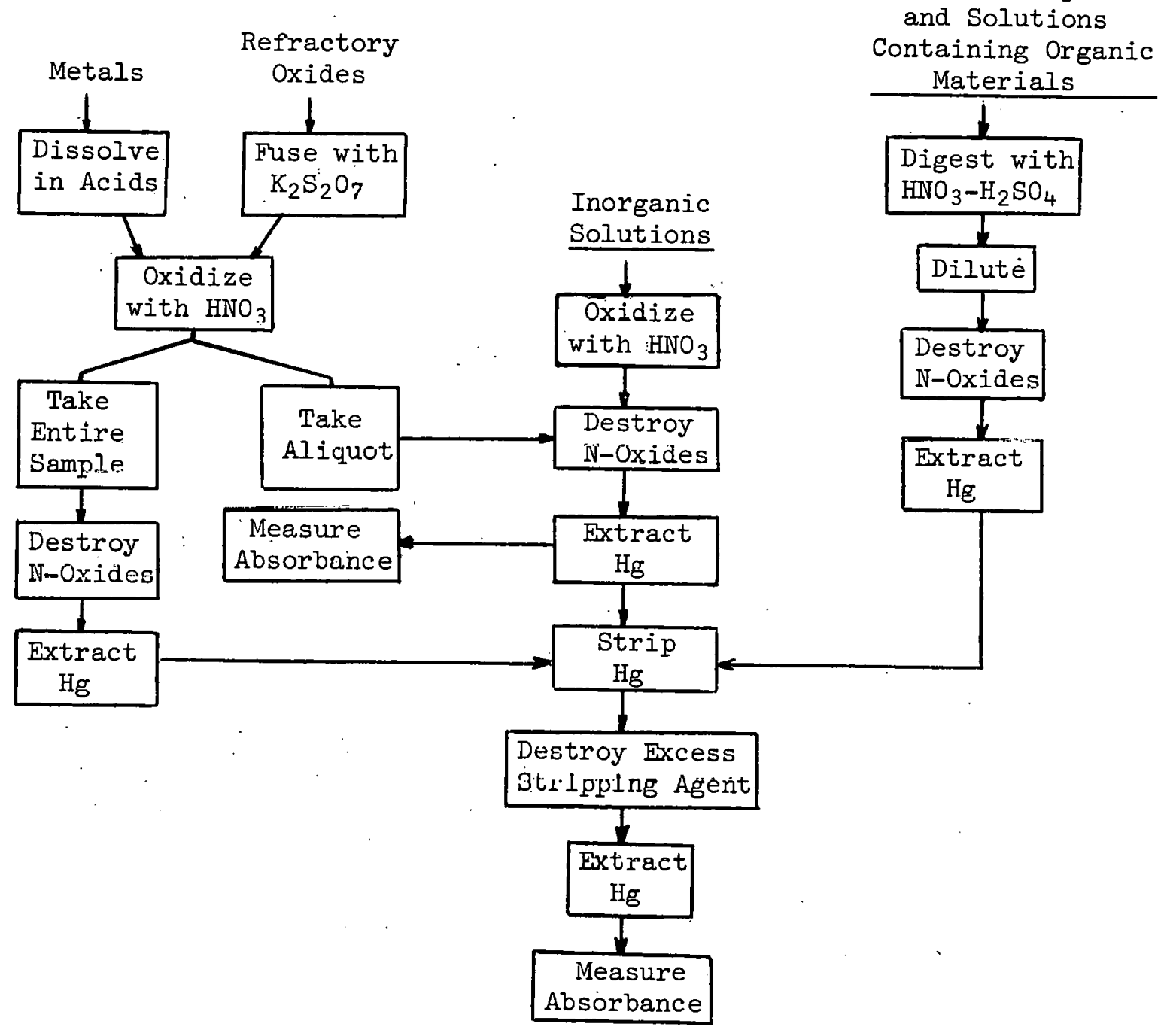

Figure 1. Analysis Schęe 
The resulting solutions from all the pretreatment procedures are analyzed by an extraction-spectrophotometric method based on the extraction of mercury(II) dithizonate into chloroform. A single extraction satisfactorily separates mercury from all the cations studied except copper and silver at molar ratios to mercury of 150 to 1 and 0.1 to 1 , respectively.

In the single extraction procedure, hydroxylamine is added to the solution from the sample pretreatment to destroy nitrite. Aniline then is added to destroy the last traces of nitrite including any nitrite that forms from nitric oxide. An EDTA-citrate buffer-complexer solution is added, and the $\mathrm{pH}$ is adjusted to $2.85 \pm 0.35$ with concentrated ammonium hydroxide and a chloroform solution of dithizone is added. After extraction, the absorbance of the complex in the separated chloroform phase is measured at $495 \mathrm{~m} \mu$.

In the double extraction procedure, the mercury first is separated from most other cations by extraction into chloroform as the dithizone complex from an acidic solution $(\leq 0.75 \mathrm{~N})$. The mercury is stripped from the chloroform phase with sodium nitrite and hydrochloric acid. Most of the excess nitrite then is destroyed with hydroxylamine. Aniline is added to destroy the last traces of nitrite and EDTA-citrate solution is added. The $\mathrm{pH}$ is adjusted to $2.85 \pm 0.35$ with sodium hydroxide, the dithizone-chloroform solution is added, and the mercury(II) dithizone complex is extracted into chloroform for measurement at $495 \mathrm{~m} \mu$.

Variables in the Spectrophotometric Method

Extraction Acidity. To extract mercury quantitatively from acidic solutions, the maximum acidity is $0.75 \mathrm{~N}$. When an EDTA solution is used, the practical $\mathrm{pH}$ range is 2.5 to 3.2. Below $\mathrm{pH} 2.5$, EDTA precipitates. Above $\mathrm{pH} \mathrm{3.2,} \mathrm{the} \mathrm{extraction} \mathrm{of} \mathrm{mercury} \mathrm{is} \mathrm{incomplete.}$

EDTA-Citrate Level. Neither the extraction nor the color intensity of the mercury(II) dithizone complex is adversely affected when up to $15 \mathrm{ml}$ of the EDTA-citrate masking solution is used in the aqueous phase.

Stripping Conditions. Mercury is stripped quantitatively from the chloroform phase with 0.5 to 1.5 mmole of sodium nitrate at $1 \mathbb{N}$ acidity. In the procedure, sodium nitrite is held at 0.75 mole and, to facilitate $\mathrm{pH}$ adjustment for the second extraction, $10 \mathrm{ml}$ of $\mathrm{IN} \mathrm{HCl}$ is used.

Destruction of Nitrite and Nitrogen Oxides. Nitrite and gaseous $\mathbb{N}$-oxides are present in sample solutions after pretreatment steps. In the double extraction procedure, nitrite and $N$-oxides are introduced in the stripping step. These must be destroyed to avoid oxidizing the dithizone in the subsequent extraction. Hydroxylamine and aniline are used for this destruction. Hydroxylamine is the principal reductant, while aniline destroys the last traces. Aniline has been found to be a more efficient scavenger than urea. It also effectively destroys nitrite generated in solution from nitric acid. 
Twenty-five mole of hydroxylamine and 1 mmole of aniline adequately. destroy nitrite before high acidity extractions. Five mole of hydroxylamine and 0.5 mole of aniline are sufficient to destroy the excess. nitrite left after the stripping step. In both cases, 5 minutes is sufficient for the hydroxylamine to react. The aniline reacts instantaneously. Neither the extraction nor the color intensity of the mercury dithizonate is affected at these levels of hydroxylamine and aniline.

\section{Diverse Ion Effects}

The effects of 35 metal ions and 8 anions on the single extraction procedure are summarized in Table.I. Only silver(I) interferes at less than a 50:1 molar ratio to mercury.

\section{Sensitivity}

With the sample sizes specified in the procedure, the sensitivity of the method is $0.5 \mathrm{\mu g} / \mathrm{g}$ for solid organic samples, $10 \mathrm{\mu g} / \mathrm{g}$ for solid inorganic samples, and $0: 2 \mu \mathrm{g} / \mathrm{ml}$ for aqueous inorganic solutions. The range of the spectrophotometric method is 1 to $35 \mathrm{\mu g}$ of mercury.

\section{Precision}

Sixty aqueous standards, equally split between the single extraction and double extraction procedures, were analyzed by six analysts. The pretreatment used was nitric acid oxidation. "The percent standard deviation ranged approximately linearly from $17 \%$ at $i \mu g$ of mercury to $5 \%$ at 25 to. 35 lug. 
Table I. DIVERSE ION EFFECTS ON THE SINGLE EXTRACTION PROCEDURE

\section{Ion or Mixture Investigated}

$\mathrm{Be}(I I), \mathrm{Bi}(I I I), \mathrm{Ca}(I I), \mathrm{Cd}(\mathrm{II}), \mathrm{Ce}(\mathrm{III})$,

$\mathrm{Co}(\mathrm{II}), \mathrm{Cr}$ (III), $\mathrm{Cs}(\mathrm{I}), \mathrm{Fe}$ (III), $\mathrm{Ge}(I V)$,

$\mathrm{Ho}(I I I), \operatorname{In}(I I I), \mathrm{La}(I I I), \mathrm{Mg}(I I), \mathrm{Mn}(I I)$,

$\mathrm{Mo}(V I), \mathrm{Ni}(I I), \mathrm{Pb}(I I), \mathrm{Sn}(I I, I V), \mathrm{Sr}(I I)$,

$\mathrm{Th}(\mathrm{IV}), \mathrm{Ti}(I V), \mathrm{U}(\mathrm{VI}), \mathrm{V}(\mathrm{V}), \mathrm{Y}(\mathrm{III}), \mathrm{Zn}(\mathrm{II})$,

$\mathrm{Zr}$ (IV)

$\operatorname{Ag}(I)$

$\operatorname{Ai}(I I I), P d(I I), P t(I V)$

$\mathrm{Cu}(\mathrm{II})$

Borate

Bromide

Chloride

Iodide, thiosulfate

Phosphate

Sulfate

Synthetic aluminum-zirconium matrix

$$
\begin{aligned}
& \mathrm{AI}(\mathrm{III}), \mathrm{Zr}(\mathrm{IV}) \\
& \mathrm{Cr}(\mathrm{VI}), \mathrm{U}(\mathrm{VI}) \\
& \mathrm{Cl}^{-1} \text { plus } \mathrm{NO}_{3}^{-1}
\end{aligned}
$$

Simulated aluminum fuel dissolver product
Tolerance Level, Ion to $\mathrm{Hg}$ Molar Ratio $\mathrm{a}, \mathrm{b}$

Each ion individualiy at 1000 $0.1^{c}$

Each ion individually at 50

$150^{c}, 750^{\mathrm{d}}$

2000

1000

$7.5 \times 10^{5}$

$50^{c}$

$3.0 \times 10^{4}$

$1.3 \times 10^{5}$

Each at 2000

Each at 50

$1 \times 10^{4}$
$\mathrm{AI}$ (III)
$4 \times 10^{4}$
$\mathrm{Cu}(\mathrm{II})$
$150^{c}$
$\mathrm{Cr}(I I I), U(V I)$
Each at 50
$\mathrm{Fe}(I I I)$.
200
$\mathrm{Mn}(I I), \mathrm{Ni}(I I)$
Each at 100
$\mathrm{NO}_{3}^{-1}$
$12 \times 10^{4}$ 


\section{TABLE I (Cont'd)}

Ion or Mixture Investigated

Tolerance Level, Ion to Hg Molar Ratio a, b

Simulated calciner product fused with potassium pyrosulfate.
$\mathrm{AI}$ (III), $\mathrm{Zr}(I V)$
Each at 2000
$\mathrm{Cr}$ (VI)
50
$K(I)$
$2.4 \times 10^{5}$
$\mathrm{SO}_{4}^{-2}$
$1.3 \times 10^{5}$

(a) Mercury level maintained at $20 \mu g\left(1 \times 10^{-4} \operatorname{mmol} \theta\right)$.
(b) Except where noted otherwise, the tolerance level listed is the highest level studied and does not represent the maximum permissible level.

(c) Maximum tolerance level.

(d) Duulje extraction procedure. 


\section{REFERENCES}

1. Lakey, L. T., Bower, J. R., IDO-14620, Rev. 1, December, 1963.

2. Analytical Methods Committee, Analyst, 90, 515 (1965). 
THIS PAGE

WAS INTENTIONALLY

LEFT BLANK 
APPENDIX

DETAILS OF PROCEDURE 


\section{A. Apparatus}

NOTE: All glassware should be boiled in $4 \mathrm{M} \mathrm{HNO}_{3}$ and rinsed with distilled water before use.

1. Absorbance cells, Pyrex, matched pairs, 1-cm and 5-cm, with covers.

2. Beakers, assorted sizes.

3.. Centrifuge tube, 50-m工.

4. Culture tube, with Teflon-lined screw cap.

5. Digestion apparatus for organic samples (Fig. $A-1$ ).

6. Filter paper, Whatman 41.

7. Fisher Filtrator.

8. Funnels, assorted sizes.

9. Graduated cylinder, 10-ml.

10. Hot plate.

11. Magnetic stirrer, with Teflon-coated stirring bars.

12. Meker 'burner.

13. Membrane filter, 0.45-ן pore size, with Milliporc fintering apparatus.

14. Miçro burner.

15. pH meter, Leeds and Northrup or Beckman, with rapillary glagecalomel electrodes or a single-probe glass-calomel electrode.

16. Pipets, macro, volumetric, assorted sizes, with suction bulb.

17. Pipets, micro, assorted sizes, with control syringe.

1:8. Pipets, Mohr, 5- and 10-ml.

19. Quartz fusion apparatus for inorganic solids. Use a 100-ml round bottom quartz flask or a $35-\mathrm{mm}$ diam $\mathrm{x}$ 6-in. quartź test tube with a $24 / 10$ outer joint in conjunction with the condenser illustrated in Fig. A-l.

20. Separatory funnels, 60-ml, with Teflon stopcocks. 
21. Separatory funnels, 500-ml, with ground glass stoppers and Teflon stopcocks.

22. Spectrophotometer, Beckman Model DU, DK, or B, or Cary Model 14.

23. Variac.

\section{B: REAGENTS}

NOTE: Use Analytical Reagent Grade chemicals and distilled water for the preparation of all reagents and throughout the procedure.

1. Ammonium hydroxide, conc.

2. Aniline hydrochloride solution, $0.5 \mathrm{M}$. Add $45 \mathrm{ml}$ of conc $\mathrm{HCl}$ to $500 \mathrm{ml}$ of water. Ada $46 \mathrm{ml}$ of freshly distilled aniline SLOWLY with efficient stirring. Transfer to a l-liter volumetric flask and dilute to volume with water. The final solution should be colorless or have only a faint pink or yellow tinge. Store in the dark and prepare a fresh solution every month.

NOTE: The aniline must be added slowly to dilute $\mathrm{HCl}$ solution to avoid excessive coloration of the solution.

3. Buffer-complexer reagent. Dissolve $37.22 \mathrm{~g}$ of $\mathrm{Na}_{2} \mathrm{EDTA} \cdot 2 \mathrm{H}_{2} \mathrm{O}$, $94.50 \mathrm{~g}$ of monochloroacetic acid, and $90.48 \mathrm{~g}$ of ammonium citrate in a 2-liter beaker with $1500 \mathrm{ml}$ of distilled water. Use sufficient cone $\mathrm{NH}_{4} \mathrm{OH}$ to insure complete dissolution ( $\mathrm{pH} \approx 3.5)$. Dilute to 2 liters with water.

4. Chloroform.

5. Dithizone stock solution, $0.0105(\mathrm{w} / \mathrm{v}) \%\left(4 \times 10^{-5} \mathrm{M}\right)$. Dissolve $0.0525 \mathrm{~g}$ of dithizone in chloroform and dilute to $500 \mathrm{ml}$ with chloroform. Store in a refrigerator when not in use.

6. Dithizone solution, $0.00105(\mathrm{w} / \mathrm{v}) \%\left(4 \times 10^{-6} \mathrm{M}\right)$. Pipet $50.00 \mathrm{ml}$ of the $0.0105 \%$ stock solution into a 500-ml volumetric flask and dilute to $500 \mathrm{ml}$ with chloroform. Store in a refrigerator when not in use.

7. Hydrochloric acid, 1.0M.

8. Hydroxylamine hydrochloride, 2.5M. Dissolve $174 \mathrm{~g}$ of $\mathrm{NH}_{2} \mathrm{OH} \cdot \mathrm{HCl}$ in $800 \mathrm{ml}$ of distilled water. Filter the solution through a $0.45-\mu$ membrane filter and dilute to l liter with water.

9. Mercuric nitrate stock solution, $500 \mu \mathrm{g} / \mathrm{ml}$. Dissolve $0.5000 \mathrm{~g}$ of redistilled mercury metal in $20 \mathrm{ml}$ of $7.5 \mathrm{M} \mathrm{HNO}_{3}$ with heating. Boil gently for $10 \mathrm{~min}$, cool, then dilute to l liter with water. Store as 40-ml units in sealed glass ampoules. 


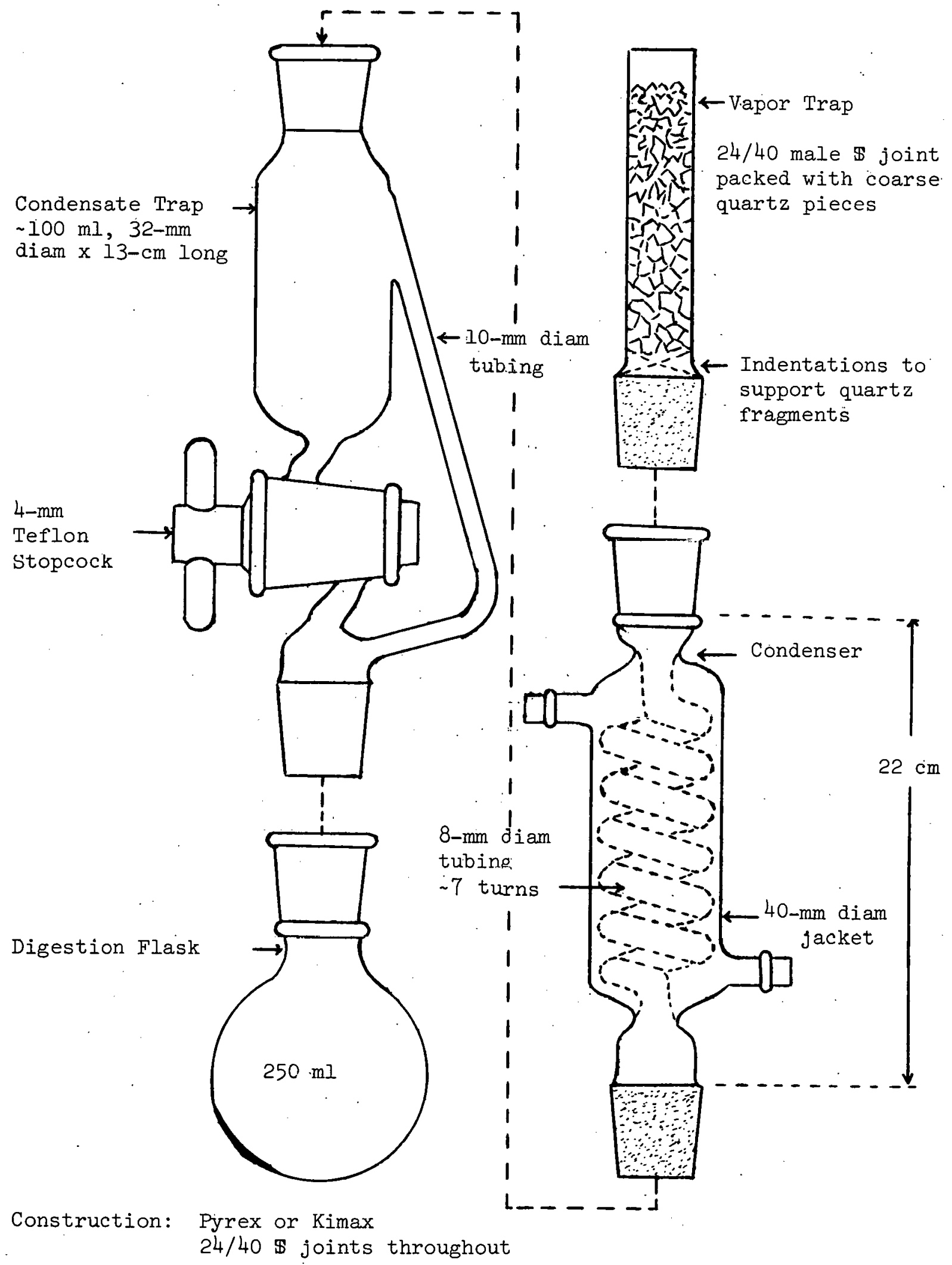

Figure A-I. Digestion Apparatus for Organic Samples 
10. Mercury calibration standard solutions.

a. Standard I, $30.00 \mu \mathrm{gg} / \mathrm{ml}$. Dilute $15.00 \mathrm{ml}$ of the mercury stock solution to $250 \mathrm{ml}$ with $0.25 \mathrm{M} \mathrm{HNO}_{3}$.

b. Standard II, $20.00 \mu \mathrm{g} \mathrm{Hg} / \mathrm{ml}$. Dilute $10.00 \mathrm{ml}$ of the mercury stock solution to $250 \mathrm{ml}$ with $0.25 \mathrm{M} \mathrm{HNO}_{3}$.

c. Standard III, $8.00 \mu \mathrm{g} \mathrm{Hg} / \mathrm{ml}$. Dilute $4.00 \mathrm{ml}$ of the mercury stock solution to $250 \mathrm{ml}$ with $0.25 \mathrm{M} \mathrm{HNO}_{3}$.

d. Standard IV, $6.00 \mu \mathrm{Hg} / \mathrm{ml}$. Dilute $3.00 \mathrm{ml}$ of the mercury stock solution to $250 \mathrm{ml}$ with $0.25 \mathrm{M} \mathrm{HNO}_{3}$.

11. Nitric acida, conc and $1 \underline{M}$.

12. Nitric acid-sulfuric acid digestion mixture. Mix, as needed, ne $n$ conc $\mathrm{H}_{2} \mathrm{SO}_{4}$ and conc $\mathrm{HNO}_{3}$ in the ratio of $1: 5$.

13. Potassium pyrosulfate, $\mathrm{K}_{2} \mathrm{~S}_{2} \mathrm{O}_{7}$.

14. Sodium hydroxide, $0.80 \mathrm{M}$. Dissolve $32.0 \mathrm{~g}$ of $\mathrm{NaOH}$ in water and dilute to 1 liter with water.

15. Sodium nitrite solution, 0.75M. Dissolve $51.76 \mathrm{~g}$ of $\mathrm{NaNO}_{2}$ in $500 \mathrm{ml}$ of water and dilute to 1 liter with water. Prepare a fresh solution every month. Store in the dark.

\section{PROCEDURE}

NOTE: Use distilled water throughout the procedure.

Mercury(II) reduces to mercury(I) or (0) by reaction with hydroxylamine, especially in weakly acidic or basic solution. Also, it may precipitate as the hydroxide from weakly acidic or neutral solutions. For these reasons, the procedure, once begun, may be interrupted only at those points where the acidity is high and hydroxylamine is absent. These points are at the end of each pretreatment procedure before any dilution or $\mathrm{pH}$ adjustment (steps $\mathrm{C}-2, \mathrm{D}-9, \mathrm{E}-2, \mathrm{~F}-9$, and $\mathrm{G}-2$ ) and at the end of the stripping step $(\underline{\mathrm{C}-1 \mathrm{2}})$ when the hydrochloric acid concentration is about $0.9 \mathrm{M}$

A. Blank

Process a reagent blank with each set of samples per the procedure selected for the analysis of samples. For aqueous samples, use 3 $\mathrm{ml}$ of distilled water in place of the sample. With inorganic solids and organic samples, omit the addition of a sample substitute, but introduce all reagents used for the samples in amounts equal to those used for the samples. 
B. Calibration and Bench Standard

Four standards are recommended for this method - two for the high range (to be measured in $1-\mathrm{cm}$ cells) and two for the low range (to be measured in 5-cm cells). If only one type of sample is to be analyzed, two appropriate standards will suffice. However, if the mercury concentrations of the samples vary over a wide range, the use of all four calibration standards will minimize repeat analyses.

Process calibration standards with each run by the same procedure as that used to analyze the samples. Use 1.00-ml aliquots of the appropriate standards. Divide the micrograms of mercury in the standard by the absorbance to obtain the conversion factor. For each of the two groups of standards, the difference between the two factors should not exceed established limits and the average of the two factors should agree with the established conversion factor within specified limits. If either of these requirements is not met, reprocess the pair or pairs of calibration standards. Contact your supervisor if difficulties are still experienced.

\section{Analysis of Aqueous Inorganic Samples of Unknown Composition}

NOTE: If the levels of diverse ions are known not to exceed the tolerance limits, the shorter single extraction procedure (Procedure G) may be used.

1. Pipet an aliquot, $5 \mathrm{ml}$ or less, containing $i$ to $35 \mu \mathrm{g}$ of mercury into a. $50-\mathrm{ml}$ centriluge tübe.

2. Add $1 \mathrm{ml}$ of conc $\mathrm{HNO}_{3}$ and immerse the centrifuge tube in a boiling water bath for 5 min.

3. Cool, dilute to about $15 \mathrm{ml}$ with water, add a small stirring bar and $2 \mathrm{ml}$ of 2. $5 \mathrm{M} \mathrm{NH}_{2} \mathrm{OH} \cdot \mathrm{HCl}$, then let stand for 5 min with intermittent stirring:

4. Add $1 \mathrm{ml}$ of $0.5 \mathrm{M}$ aniline hydrochloride.
The use of a wide-mouth test tube such as a 50-ml centrifuge tube facilitates $\mathrm{pH}$ adjustment in step 6. Refer to Table I for information on tolerance levels for diverse ions.

Nitric acid oxidizes $\mathrm{H}(0, I)$ to $\mathrm{Hg}$ (II). Prolonged digestion will lead to loss of mercury by volatilization. If brown $\mathrm{NO}_{2}$ fumes are observed, aspirate the fumes with mild suction before adding the hydroxylamine hydrochloride.

Mercury(II) reduces with standing times longer than $10 \mathrm{~min}$. 
5. Add $5 \mathrm{ml}$ of the buffercomplexer solution.

6. With the aid of a $\mathrm{pH}$ meter, adjust the pH to $2.85 \pm 0.35$ with conc $\mathrm{NH}_{4} \mathrm{OH}$.

7. Transfer the sample quantitatively to a 60-ml separatory funnel with water rinses.

8. Add approximately $15 \mathrm{ml}$ of $0.00105 \%$ dithizone-chloroform solution and shake vigorously for $30 \mathrm{sec}$. Let the two layers separate, then swirl the separatory funnel to settle the floating droplets of chloroform.

9. Drain the lower chloroform layer into a clean $60-\mathrm{ml}$ separatory funnel.

10. Fxtract the residual aqueous phase in the original separatory funnel for $15 \mathrm{sec}$ with $5 \mathrm{ml}$ of chloroform and drain the chloroform into the clean separatory funnel.

11. To the dithizone-chloroform. extract, pipet $10 \mathrm{ml}$ of 1. OM HCl with a volumetric pipet and $1 \mathrm{ml}$ of $0.75 \mathrm{M}$ $\mathrm{NaNO}_{2}$ solution. Stopper and shake for $30 \mathrm{sec}$.

Do not transfer any of the aqueous phase. A small amount of the chloroform layer left in the separatory funnel will be recovered in step 10. Observe the color of the chloroform solution. If it is golden-yellow or nearly so with very little blue-green color of free dithizone, extract the residual aqueous phase in the original separatory funnel with $10 \mathrm{ml}$ of the $0.00105 \%$ chloroform-dithizone solution and drain the chloroform extract into the clean separatory funnel. If the second extract still lacks the blue-green color of free dithizone, discard the sample and process a new, smaller aliquot.

Do not transfer any of the aqueous phase. Discard the aqueous phase. The two organic phases (steps 9 and 10) are combined.

The nitrite destroys the dithizone and returns the mercury to the aqueous phase. 
12. Lèt the two phases separate, then drain and discard the lower chloroform layer.

13. To the residual aqueous phase, add $2 \mathrm{ml}$ of $2.5 \mathrm{M}$ $\mathrm{NH}_{2} \mathrm{OH} \cdot \mathrm{HCl}$. React for $\overline{5} \mathrm{~min}$ with intermittent swirling.

14. Rinse the separatory funnel with a little water, then add $1 \mathrm{ml}$ of $0.5 \mathrm{M}$ aniline hydrochloride solution. Swirl to mix.

15. Add $5 \mathrm{ml}$ of the buffercomplexer solution, swirl to $\mathrm{mix}$, then pipet $10 \mathrm{ml}$ of $0.80 \mathrm{M} \mathrm{NaOH}$ with a volumetric pipet to adjust the $\mathrm{pH}$ to " the range $2.85 \pm 0.35$.

16. Pipet precisely $15.00 \mathrm{ml}$ of $0.00105 \%$ dithizone-chloroform solution, stopper, and extract for $15 \mathrm{sec}$.

17. Let the phases separate, then drain the lower chloroform phase into a 25-mI screw-cap culture tube. Measure the absorbance of the chloroform phase at 495 $m \mu$ against the reagent blank in $1-\mathrm{cm}$ ( 5 to $35 \mu \mathrm{g}$ of mercury) or $5-\mathrm{cm}$ ( 1 to 10 $\mu \mathrm{g}$ of mercury) celis.
Take care that none of the aqueous layer is lost in the separation.

Mercury(II) reduces with standing. times longer than $10 \mathrm{~min}$.

Rinse the stopper and the neck of the flask carefully to remove any traces of $\mathrm{NaNO}_{2}$ present.

The $\mathrm{pH}$ at this step is critical. Measure the $\mathrm{pH}$ of the blank with a $\mathrm{pH}$ meter to see if it is within the required range. If it is not, measure the $\mathrm{pH}$ of all samples. Adjust the $\mathrm{pH}$, as necessary, to $2.85 \pm 0.35$ with $1 \mathrm{M} \mathrm{HCl}$ or $0.80 \mathrm{M}$ $\mathrm{NaOH}$.

The extraction time must be kept short to minimize the extraction of copper.

When in doubt, measure the absorbance with $5-\mathrm{cm}$ cells first. This will permit subsequent measurements with 1-cm cells.

The color of the chloroform-dithizone extract should show the presence of excess unreacted dithizone, i.e., a bluish-green cast. If not, discard the sample and process a new smaller aliquot.

The walls of the tube adsorb water droplets which otherwise interfere. If neciessary, centrifuge the tube.

Under proper conditions, the color of the chloroform extract is stable for at least $2 \mathrm{hr}$. If slow but noticeable "bleaching" is observed, the nitrite probably was not destroyed adequately in steps 13 and 14. Discard the sample and process a new one. 
D. Analysis of Inorganic Solids With Greater Than $100 \mu \mathrm{g} / \mathrm{g}$ Levels of Mercury

1. Transfer a 0.1-g sample containing greater than 10 $\mu g$ of mercury to the quartz fusion apparatus.
This procedure is intended primarily for inorganic solids such as alumina and alumina-zirconia calcined materials that are diffi- cult to dissolve. Dissolve metals and alloys under reflux in appropriate mineral acids and analyze per Procedure $\underline{\text { C. }}$
2. Add $3.0 \mathrm{~g}$ of $\mathrm{K}_{2} \mathrm{~S}_{2} \mathrm{O}_{7}$.

3. Assemble the fusion apparatus. Turn on the cooling water and tilt the apparatus to about a $45^{\circ}$ angle.

4. With a Meker burner, fuse the sample repeatedly until the melt clears.

5. Turn off the cooling water and return the apparatus to the upright position.

6. Add $6 \mathrm{ml}$ of conc $\mathrm{HNO}_{3}$ through the condenser and heat the mixture with a micro burner until the point of condensation just reaches the top of the condenscr or until the start of bumping.

7. Cool slightly, turn on the cooling water, and rinse the condenser with 20 to 25 $\mathrm{ml}$ of $\mathrm{IM} \mathrm{HNO}_{3}$.

8. Remove the fusion flask or tube and place it in a boiling water bath until the liquid clears and most of the solids dissolve.

9. Cool the solution and filter it through a 0.45- $\mu$ membrane filter directly into a 250$\mathrm{ml}$ volumetric flask. Use at least three 10-m.l portions of $\mathrm{IM}^{\mathrm{MNO}} \mathrm{HN}_{3}$ for the transfer. and washing and a Fisher
During fusion, mercury is volatilized into the condenser possibly as metallic mercury. The purpose of the $\mathrm{HINO}_{3}$ reflux is to recover the volatilized mercury.

It is not necessary to dissolve the solids completely. 
Filtrator-Millipore setup for the filtration.

10. Dilute to volume with water and mix well.

11. Pipet an aliquot, $25 \mathrm{ml}$ or less, containing 1 to $35 \mathrm{\mu g}$ of mercury into a 50-ml beaker.

12. Continue per. Procedure $\mathrm{C}$ beginning at step $\underline{3}$.

If the observed net absorbance of the sample corresponds to less than 1 g of mercury, select a larger aliquot (if this is permissible) in step 1 il. With a 25-ml aliquot of the diluted sample, the lower limit of determinability is $100 \mathrm{ppm}$ of mercury in the original solid sample. If greater sensitivity is required, reanalyze the original solid sample per Procedure E.

E. Analysis of Inorganic Solids With Less Than $100 \mu \mathrm{g} / \mathrm{g}$. Levels of Mercury

1. Dissolve a 0.1-g sample per steps 1 through 8 of Procedure $\underline{\text { D. }}$.

2: Cool the solution, then filter the solution through a Whatman 41 filter paper into a 500-ml separatory funnei. Use three 10-ml portions of $\mathrm{IM}^{\mathrm{MNO}} \mathrm{HN}_{3}$ to rinse the fusion flask and the filter paper.

3. Dilute to $250 \mathrm{ml}$ with distilled water.

The acidity must be reduced to $0.75 \underline{N}$ or less.

4. Add $5 \mathrm{ml}$ of $2.5 \mathrm{M} \mathrm{NH} \mathrm{NH}_{2} \mathrm{OH} \cdot \mathrm{HCl}$ and let stand for 5 min with Mercury(II) reduces with standing intermittent swirling.

5. Rinse the separatory funnel with water, then add $2 \mathrm{ml}$ of $0.5 \mathrm{M}$ aniline hydrochloride solution. 
6. Extract for $30 \mathrm{sec}$ with 10 $\mathrm{ml}$ of $0.00105 \%$ dithizonechloroform solution. Drain the lower chloroform phase into a $60-\mathrm{ml}$. separatory funnel.

7. Repeat step $\underline{6}$.

8. Repeat step 6 using $10 \mathrm{ml}$ of chloroform in place of the dithizone-chloroform solution. Discard the aqueous phase.

9. Continue per Procedure $\mathrm{C}$ beginning at step 11 .
Considerable pressure is often built up within the separatory funnel. Cover the stopper with a tissue paper and remove the stopper carefully.

F. Analysis of Organic Samples and Inorganic Samples Containing Organic Matter

1. Weigh or pipet a sample containing 1 to $35 \mu \mathrm{g}$ of mercury into the flask of the digestion apparatus (Fig. A-I).
This procedure has been found to be satisfactory for $2-g$ samples of organic matter such as vegetation. If larger samples must be processed to reach the desired sensitivity, process separate 2-g samples per steps $F-1$ through F-15, combine the dithizonechloroform and chloroform extracts of steps $\mathrm{F}-13$ through $\mathrm{F}-15$, then complete the determination per step 16.

2. Add $15 \mathrm{ml}$ of freshly prepared $\mathrm{HNO}_{3}-\mathrm{H}_{2} \mathrm{SO}_{4}$ digestion mixture.

3. Assemble the digestion apparatus per Fig. A-l, turn on the cooling water, and heat the sample with a heating mantle controlled by a Variac. Boil vigorously and collect the distillate in the condensate trap. Continue the digesliun until only 2 to 3 ml of acid remains and $\mathrm{H}_{2} \mathrm{SO}_{4}$ fumes and charring is observed.

A Variac setting of 105 to 110 is recommended. 
7. Return the condensate to the digestion flask, cool slightly, then admit about $50 \mathrm{ml}$ of water through the top of the digestion apparatus.

8. Reflux for $5 \mathrm{~min}$, or longer if necessary, to dissolve precipitated sulfate salts.

9. Disassemble the digestion apparatus. Rinse each component with water and collect the rinses in the flask.

10. Transfer the contents of the flask quantitatively to a 500-ml separatory t'unnel with water rinses and dilute to about $400 \mathrm{ml}$ with water.

11. Add $10 \mathrm{ml}$ of $2.5 \mathrm{M} \mathrm{NH}_{2} \mathrm{OH} \cdot \mathrm{HCl}$, mix well, then let stand for 5 min. Swirl intermittently during the 5-min period.

12. Add $2 \mathrm{ml}$ of $0.5 \mathrm{M}$ aniline nỹarochlorìde sôlütion and mix well.

13. Extract the mercury with a 10-ml portion of $0.00105 \%$ dithizone-chloroform solution for $30 \mathrm{sec}$. Drain the lower chloroform layer into a 60-ml separatory funnel.

14. Repeat step 13.

15. Repeat step 13 using $10 \mathrm{ml}$ of chloroform in place of the dithizone-chloroform solution. Discard the aqueous phase.

16. Continue per Procedure $\underline{\mathrm{C}}$ beginning at step 1 l.
Admit the water slowly.

Rinse the side arm of the condensate trap also.

For quantitative extraction of the mercury, the acidity must be $0.75 \mathrm{~N}$ or less.

Mercury(II) reduces with standirg times longer than $10 \mathrm{~min}$.

Considerable pressure is often built up during the extraction. Cover the stopper with a tissue paper and remove the stopper carefully.

Combine the organic phases.

Combine this organic phase with the two previous organic phases in the 60-ml separatory funnel. 
G. Analysis of Aqueous Inorganic Samples of Known Composition (Single Extraction Procedure)

NOTE: If the composition of the sample is unknown or is known to contain copper at concentrations that exceed the tolerance limits; Procedure $\underline{\mathrm{C}}$ must be used.

1. Pipet an aliquot, $5 \mathrm{ml}$ or less, that contains 1 to 35 $\mu \mathrm{g}$ of mercury into a 50-ml centrifuge tube.

2. Add $1 \mathrm{ml}$ of conc $\mathrm{HNO}_{3}$ and immerse the centrifuge tube in a boiling water bath for $5 \min$.

3. Cool, dilute to about $25 \mathrm{ml}$ with water, add $2 \mathrm{ml}$ of 2. $5 \mathrm{M} \mathrm{NH}_{2} \mathrm{OH} \cdot \mathrm{HCl}$, then let stand 5 min with intermittent swirling.

4. Add $1 \mathrm{ml}$ of $0.5 \mathrm{M}$ aniline hydrochloride.

5. Add $10 \mathrm{ml}$ of the complexerbuffer solution and adjust the $\mathrm{pH}$ to $2.85 \pm 0.35$ with conc $\mathrm{NH}_{4} \mathrm{OH}$.

6. Transfer the sample quantitatively to a 60-ml separatory funnel with water rinses.

7. Add exactly $15.0 \mathrm{ml}$ of $0.00105 \%$ dithizone-chloroform solution and extract for exactly $15 \mathrm{sec}$.

8. Drain the lower chloroform layer into a 50-ml culture. tube.
The sample must not contain more than 4 mmole of aluminum nor more than 0.03 mmole of copper(II). See Table I for the tolerance levels of other ions.

Nitric acid oxidizes $\mathrm{Hg}(O, I)$ to $\mathrm{Hg}$ (II). Prolonged digestion will lead to loss of mercury by volatilization.

If much brown $\mathrm{NO}_{2}$ fumes are observed, aspirate the fumes with mild suction before adding the $\mathrm{NH}_{2} \mathrm{OH} \cdot \mathrm{HCl}$.

Mercury(II) reduces with standing times longer than $10 \mathrm{~min}$.

The extraction time must be kept short to minimize the extraction of copper.

The walls: of the culture tube adsorb water droplets which otherwise interfere. If necessary, centrifuge the tube. 
9. Measure the absorbance of chloroform extract against the reagent blank at $495 \mathrm{m \mu}$ in $1-\mathrm{cm}$ ( 5 to $35 \mu \mathrm{g}$ of mercury) or $5-\mathrm{cm}$ ( 1 to 10 $\mu \mathrm{g}$ of mercury) cells.
When in doubt, measure the absorbance with 5-cm cells first. This will permit subsequent measurements with l-cm cells.

The color of the chloroformdithizone extract should show the presence of excess unreacted dithizone, i.e., a bluish-green cast. If not, discard the sample. and process a new smaller aliquot.

Under proper conditions, the color of the chloroform extract is stable for at least $2 \mathrm{hr}$. If slow but noticeable "bleaching" is observed, the nitrite probably was not destroyed adequately in / steps $\underline{3}$ and $\underline{4}$. 